\title{
A disease-associated cellular immune response in type 1 diabetics to an immunodominant epitope of insulin
}

\author{
David G. Alleva, ${ }^{1}$ Paul D. Crowe, ${ }^{1}$ Liping Jin, ${ }^{1}$ William W. Kwok, ${ }^{2}$ \\ Nicholas Ling, ${ }^{1}$ Michael Gottschalk, ${ }^{3}$ Paul J. Conlon, ${ }^{1}$ \\ Peter A. Gottlieb, ${ }^{4}$ Amy L. Putnam, ${ }^{4}$ and Amitabh Gaur ${ }^{1}$ \\ 1 Immunology D epartment, N eurocrine Biosciences Inc., San Diego, California, USA \\ Virginia M ason Research Center, Seattle, Washington, USA \\ 3Pediatric and Adolescent Endocrinology and Diabetes, Children's Hospital and Health Center, San Diego, California, USA \\ 4 University of Colorado Health Sciences Center, Barbara Davis Center for Childhood Diabetes, Denver, Colorado, USA
}

Address correspondenceto: D avid G. Alleva, Immunology D epartment, Neurocrine Biosciences Inc., 10555 Science Center D rive, San Diego, California 92121-1102, USA. Phone: (858) 658-7769; Fax: (858) 658-7602; E-mail: dalleva@neurocrine.com.

Received for publication September 22, 1999, and accepted in revised form N ovember 29, 2000.

The 9-23 amino acid region of theinsulin $B$ chain $\left(B_{(9-23)}\right)$ is a dominant epitoperecognized by pathogenic $T$ lymphocytes in nonobese diabetic mice, the animal model for type 1 diabetes. We describe herein similar $\mathrm{B}_{(9-23)}$-specific $\mathrm{T}$-cell responses in peripheral lymphocytes obtained from patients with recent-onset type 1 diabetes and from prediabetic subjects at high risk for disease. Short-term T-cell lines generated from patient peripheral lymphocytes showed significant proliferative responses to $B_{(9-23)}$, whereas lymphocytes isolated from HLA and/or age-matched nondiabetic normal controls were unresponsive. Antibody-mediated blockade demonstrated that the response was H LA class II restricted. Use of thehighly sensitive cytokine-detection ELISPOT assay reveal ed that these $B_{(9-23)}$-specific cells were present in freshly isolated lymphocytes from only the type 1 diabetics and prediabetics and produced the proinflammatory cytokine IFN $-\gamma$. This study is, to our knowledge, the first demonstration of a cellular response to the $\mathrm{B}_{(9-23)}$ insulin epitope in human type 1 diabetes and suggests that themouseand human diseases havestrikingly similar autoantigenic targets, a featurethat should facilitate development of antigen-based therapeutics.

J. Clin. Invest. 107:173-180 (2001).

\section{Introduction}

Genetic and environmental factors cooperate to precipitate type 1 diabetes, a spontaneous organ-specific autoimmune disease in humans and in the nonobese diabetic (NOD) mouse (reviewed in refs. 1, 2). The disease is characterized by an initial leukocyte infiltration into the pancreas that eventually leads to inflammatory lesions within islets, a process called "insulitis." Overt diseaseis characterized by thesubsequent destruction of insulin-producing $\beta$ cells within the islets, leading to impaired glucose metabolism and attendant complications that arehallmarks of type 1 diabetes.

Although the critical events that trigger the autoreactive process in type 1 diabetes areunclear, destruction of islet $\beta$ cells in both diabetic patients and the NOD mouse appears to be mediated by the activation of autoreactive T cells that recognizeseveral islet $\beta$-cell antigens ( $\beta C A s)$, including insulin, glutamic acid decarboxylase (GAD) 65 and 67 isotypes, heat shock protein 60 , and some uncharacterized $\beta C$ As (reviewed in refs. 1-3). Theseantigen specificities havebeen defined in primary T-cell assays and by the generation of T-cell lines and clones from type 1 diabetic patients and high-risk first-degreer retatives and from lymph nodes, spleens, and pancreata of NOD mice. The majority of pathogenic $\mathrm{CD} 4^{+} \mathrm{T}$-cell clones derived from pancreata of NOD mice with insulitis or frank diabetes not only recognize insulin, but react specifically with the 9-23 peptide region of the $B$ chain (4-6). M oreover, the 15-23 region of theinsulin $B$ chain was identified as a major antigenic epitope recognized by a pathogenic $\mathrm{CD} 8^{+} \mathrm{T}$-cell clone after screening an NOD islet $\beta$-cell cDNA library expressed in COS cells (expressing M HC class I) as antigen presenting cells (7). In addition, the use of fluorescent-labeled M HC class I tetrameric complexes bound to the $B$ chain 15-23 peptide demonstrated that as much as $87 \%$ of $C D 8^{+} T$ cells in the pancreata from young NOD mice recognized this epitope (7). This finding is consistent with the fact that insulin is the only type 1 diabetes-associated autoantigen that has an expression limited to islet $\beta$ cells and is the most abundantly produced protein by that tissue. Although cellular responses to GAD appear to berequired for theinitial antipancreatic response in the NOD (8), anti-insulin cellular responses occur shortly after the initial anti-GAD response, presumably as a result of antigenic-spreading within the pancreas (3), and correlate with most of the islet $\beta$-cell destruction in theNOD mouse $(5,6,8,9)$.

The $B_{(9-23)}$ response is strongly associated with overt disease in the NOD mouse; however, it is unknown whether this response is observed in human type 1 diabetes. Theinsulin $\mathrm{B}_{(9-23)}$ amino acid sequenceis identical 
in miceand in humans, which suggests that this epitope may play an immunodominant and perhaps a pathogenic rolein human diseaseas well. Indeed, a diagnostic characteristic of human type 1 diabetes is the pronounced humoral response to proinsulin and whole insulin proteins, which is evident by elevated serum levels of anti-insulin antibodies (IAAs) observed in predisease (i.e., high-risk individuals) and patients with recentonset type 1 diabetes $(1,10)$. However, there is no compelling evidence for a pathogenic role of autoantibodies in either human or murine type 1 diabetes (11). Rather, thedisease is predominantly mediated by autoreactivecellular responses to $\beta C A s$ (2). Unexpectedly, however, theT-cell proliferativeresponses to proinsulin or to the wholeinsulin protein do not appear elevated in prediabetic patients or in thosewith recent-onset type 1 diabetes compared with normal control subjects (12-18). Although this observation appears inconsistent with the predominant anti-insulin cellular responses found in the NOD disease, it is theinsul in $\mathrm{B}_{(9-23)}$-specific responsethat is characteristic of the murinedisease (4-6), and not necessarily theresponseto wholeinsulin protein. Therefore, weaddressed whether a more restricted-epitoperesponse to insulin is also characteristic of human type 1 diabetes by determining whether elevated insulin $\mathrm{B}_{(9-23)}$-specific cellular responses exist in prediabetic and recent-onset type 1 diabetic patients.

\section{Methods}

Subjects. Written and informed consent was obtained from 12 patients with recent-onset type 1 diabetes (P1-P12), five prediabetic first-degreerelatives of type 1 diabetics who wereat high risk for diabetes ( $\mathrm{H} 1-\mathrm{H} 5), 26$ nondiabetic normal control subjects (C1-C26), and two type 2 diabetic control subjects (C27 and C28) who have received insulin therapy for 5 and 20 years, respectively, before enrollment in this study (Tables 1 and 2). Patients were considered to have a recent-onset status within 3 months (i.e., 130 days) of diagnosis. Criteria for patient diagnosis for type 1 diabetes werediabetic ketosis and ketoacidosis, polyuria, polydypsia, and weight loss, followed by assessment of serum autoantibody levels and human leukocyte antigen (HLA) typing.

Serum levels of anti-GAD 65 and anti-IA-2 antibody were measured by a liquid-phase competitive RIA as described previously $(19,20)$ and IAA levels were measured by a protein A microassay (21). Positive and negative control sera were included that wereused to calculate an index for antibody levels as described by the following equation: (unknown sample value- negative control value)/ (positivecontrol value- negative control value). The upper normal limits for each autoantibody serum level wereestablished as threetimes the 100th percentilein 241 healthy controls, using the Receiver O perator Curve analysis, which weregreater than 0.071 (IA2), greater than 0.032 (GAD 65), and greater than 0.01 (insulin) (22). M easurement of serum levels of autoantibodies from the 12 type 1 diabetic patients showed that ten patients werepositivefor anti-GAD 65 antibody, five were positivefor anti-IA-2 antibody, and only two were positive for anti-insulin antibody (Table 3). Interestingly, Patient P8 was the only patient who demonstrated a dramatic endogenous anti-insulin antibody response, which was accompanied by substantial anti-GAD 65 and anti-IA-2 antibody responses. Criteria for assessing prediabetics at high-risk of diabetes were the following: (a) first-degree relative, (b) expression of disease-associated HLA-haplotypes (i.e., HLA-D R3/4,-D Q 2/8; Table1), and (c) positivefor serum autoantibodies (Table3). Autoantibody levels were secondary to first-degree relative status and HLA haplotype, as only three of four subjects tested were positivefor autoantibodies.

HLA typing was done by PCR amplification with sequence-specific primers for DR and DQ alleles (23) at theUniversity of California, Los Angeles, TissueTyping Laboratory. The majority of type 1 diabetic patients expressed high-risk DQ and DR alleles [i.e., HLA-DQ 8 (DQB1*0302; 33\%), -DQ2 (DQB1*0201; 58\%), -DR3 (DRB1*0301; 58\%) and -DR4 (DRB1*0401 to 0405; 42\%)] (Table 1), which werealso represented in 12 of the first 14 nondiabetic control subjects [i.e., HLA-DQ8 (DQB1*0302; 64\%), -DQ2 (DQB1*0201; 21\%), -DR3 (DRB1*0301; 21\%) and -DR4 (DRB1*0401 to 0405; 79\%)] (Table 2). In fact, the high-risk DR4/DQ 8 or DR3/DQ 2 combinations were present in ten of the 12 patients and in 14 of the 26 nondiabetic normal control subjects. The average age of the type 1 diabetic patient group was $11 \pm 3$ years (range: 8-15 years), which was represented in three nondiabetic, first-degree relative normal control subjects (C11-C13; $11 \pm 1$ years) and in four of five high-risk first-degree relative controls (i.e., $12 \pm 0.3$ years). Control-patient sibling matches included $\mathrm{C} 11$ with $\mathrm{P} 1, \mathrm{C} 12, \mathrm{C} 13$, with $\mathrm{P} 2$ and $\mathrm{H} 5$ with $\mathrm{P} 12$, whereas control patient HLA-haplotype matches were C5 with $\mathrm{P} 9, \mathrm{C} 11$ with $\mathrm{P} 2$, and $\mathrm{H} 5$ with both $\mathrm{P} 11$ and

\section{Table 1}

Age, sex, and HLA haplotypes of type 1 diabetic patients and prediabetic individuals at high risk for diabetes

\begin{tabular}{|c|c|c|c|c|}
\hline \multicolumn{5}{|c|}{ Type 1 diabetic patients } \\
\hline \multirow{2}{*}{$\begin{array}{l}\text { Subjec } \\
\text { ID }\end{array}$} & \multirow{2}{*}{ Age } & Sex & \multicolumn{2}{|c|}{ HLA haplotypes } \\
\hline & & & DR alleles & DQ alleles \\
\hline $\begin{array}{l}\text { P1 } \\
\text { P2 } \\
\text { P3 } \\
\text { P4 } \\
\text { P5 } \\
\text { P6 } \\
\text { P7 } \\
\text { P8 } \\
\text { P9 } \\
\text { P10 } \\
\text { P11 }\end{array}$ & $\begin{array}{c}12 \\
14 \\
10 \\
8 \\
10 \\
15 \\
12 \\
9 \\
14 \\
9 \\
12\end{array}$ & $\begin{array}{l}M \\
M \\
F \\
F \\
F \\
M \\
F \\
M \\
M \\
M \\
M \\
M\end{array}$ & $\begin{array}{l}\text { DRB1*0402/*0405 } \\
\text { DRB1*0401/*0402 } \\
\text { DRB1*0102/*0301 } \\
\text { DRB1*0301/*1302 } \\
\text { DRB1*0101/*0401 } \\
\text { DRB1*0101/*0301 } \\
\text { DRB1*1302/*1503 } \\
\text { DRB1*0401 } \\
\text { DRB1*0301/*0402 } \\
\text { DRB1*0301 } \\
\text { DRB1*0101/*0301 } \\
\text { DRB1*0101/*0301 }\end{array}$ & $\begin{array}{l}\text { DQB } 1 * 0302 \\
\text { DQB } 1 * 0302 \\
\text { DQB } 1 * 0201 / * 0501 \\
\text { DQB } 1 * 0201 / * 0604 \\
\text { DQB } 1 * 0302 / * 0501 \\
\text { DQB } 1 * 0201 / * 0501 \\
\text { DQB1*0502/*0602 } \\
\text { DQB } 1 * 0301 \\
\text { DQB } 1 * 0201 / * 0302 \\
\text { DQB } 1 * 0201 \\
\text { DQB } 1 * 0201 / * 0501 \\
\text { DQB } 1 * 0201 / * 0501\end{array}$ \\
\hline \multicolumn{5}{|c|}{ Prediabetic high-risk subjects (have not received insulin therapy) } \\
\hline $\begin{array}{l}\mathrm{H} 1 \\
\mathrm{H} 2 \\
\mathrm{H} 3 \\
\mathrm{H} 4\end{array}$ & $\begin{array}{l}12 \\
12 \\
41 \\
13\end{array}$ & $\begin{array}{l}\mathrm{F} \\
\mathrm{M} \\
\mathrm{F} \\
\mathrm{M} \\
\mathrm{M}\end{array}$ & $\begin{array}{l}\text { DRB } 1 * 0301 / * 0401 \\
\text { DRB1*0101/*0401 } \\
\text { DRB1*0401/*1501 } \\
\text { DRB1*0101/*0701 } \\
\text { DRB1*0101/*0301 }\end{array}$ & $\begin{array}{l}\text { DQB1*0201/*0302 } \\
\text { DQB1*0302/*0501 } \\
\text { DQB1*0302/*0602 } \\
\text { DQB B } 1 * 0201 / * 0501 \\
\text { DQB } 1 * 0201 / * 0501\end{array}$ \\
\hline
\end{tabular}


Table 2

Age, sex, and HLA haplotypes of normal nondiabetic and type 2 diabetic control subjects

Normal nondiabetic controls

\begin{tabular}{|c|c|c|c|}
\hline \multirow{2}{*}{$\begin{array}{l}\text { Subject A } \\
\text { ID }\end{array}$} & \multirow[t]{2}{*}{ Sex } & \multicolumn{2}{|c|}{ HLA haplotypes } \\
\hline & & DR alleles & DQ alleles \\
\hline $\mathrm{C} 1$ & $M$ & DRB $1 * 0404$ & DQB1*0302 \\
\hline 32 & M & DRB1*0401/*1101 & $\mathrm{DQB} 1 * 0301 / * 0302$ \\
\hline 47 & $M$ & DRB $1 * 0404 / * 1501$ & $\mathrm{DQB} 1 * 0302 / * 0602$ \\
\hline C4 & $\mathrm{F}$ & DRB1*0401/*1101 & DQB1*0301/*0302 \\
\hline 35 & M & DRB1*0301/*0404 & $\mathrm{DQB} 1 * 0201 / * 0302$ \\
\hline 35 & $M$ & DRB1*0407/*1401 & $\mathrm{DQB} 1 * 0302 / * 0501$ \\
\hline 51 & $M$ & DRB $1 * 0401 / * 0701$ & $\mathrm{DQB} 1 * 0201 / * 0301$ \\
\hline 48 & $M$ & DRB1*0101/*0401 & DQ B1*0301/*0501 \\
\hline 33 & $M$ & DRB1*0101/*0301 & DQB1*0301/*0501 \\
\hline 36 & M & DRB1*1501 & DQB1*0602 \\
\hline 10 & $\mathrm{~F}$ & DRB1*0401/*0402 & DQB1*0302 \\
\hline 14 & $\mathrm{~F}$ & DRB1*0405/*1602 & DQB1*0301/*0302 \\
\hline 11 & $\mathrm{~F}$ & DRB1*0405/*1602 & $\mathrm{DQB1} * 0301 / * 0302$ \\
\hline 27 & $F$ & DRB1*0401/*0801 & DQB1*0302/*0402 \\
\hline 59 & $M$ & DR15 & $31 * 0602$ \\
\hline 19 & $\mathrm{~F}$ & DR15/8 & $B 1 * 0602$ \\
\hline 33 & $M$ & ND & DQB1*0602 \\
\hline & $\mathrm{F}$ & DR15/7 & $\mathrm{DQB1} * 0303 / * 0602$ \\
\hline 72 & M & ND & \\
\hline 5 & $\mathrm{~F}$ & DR15/16 & $\mathrm{DQB} 1 * 0502 / * 0602$ \\
\hline 70 & $\mathrm{~F}$ & DR6/11 & DQ $1 / 7$ \\
\hline 20 & $F$ & DR4/15 & DQB1*0301/*0602 \\
\hline & F & ND & DQB1*0602 \\
\hline & 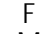 & ND & DQB1*0602 \\
\hline & M & ND & DQB1*0602 \\
\hline & - & DR11/15 & DQB1*0301/*060 \\
\hline
\end{tabular}

Type 2 diabetic controls

\begin{tabular}{llll}
$C 27$ & 84 & $M$ & $N D$ \\
$C 28$ & 65 & $M$ & $N D$ \\
\hline
\end{tabular}

P12. All recent-onset diabetic patients received human insulin therapy after diagnosis, which ranged from 2 to 127 days (mean $=64$ days) before blood sampling. To control for the possibility that $\mathrm{B}_{(9-23)}$-specific immune responses developed as a result of insulin therapy, responsiveness to $B_{(9-23)}$ was studied in two patients (C27 and C28) that had type 2 diabetes (i.e., a non-autoimmune-mediated disease) who received insulin therapy because of their suppressed insulin production. In addition, fivehigh-risk first-degreerelatives of type 1 diabetics who had not received insulin therapy were also studied for responsiveness to $B_{(9-23)}$. This study was approved by the Investigational Review Boards of the University of California, San Diego, and Children's Hospital and $\mathrm{H}$ ealth Center.

Peptides, reagents, and tissueculturemedium. The following peptides were synthesized by a solid-phase method as described el sewhere (24): human insulin B-chain (923) amide $\left(B_{(9-23)}\right)$ [SHLVEALYLVCGERG], sperm whale myoglobin 110-121 (SWM), and biotinylated herpes simplex virus peptide-2 (HSV-2) VP16 430-444 (EEVDMTPADALDDFD). M edium used for all cell cultures and assays was DM EM containing high glucose (Cellgro, Herndon, Virginia, USA) supplemented with $2 \mathrm{mM}$ L-glutamine, $10 \mathrm{mM}$ HEPES (Cellgro), nonessential amino acids (Sigma Chemical Co., St Louis, M issouri, USA), $1 \mathrm{mM}$ sodium pyruvate, $50 \mu \mathrm{g} / \mathrm{ml}$ gen- tamicin, $126 \mu \mathrm{g} / \mathrm{ml}$ L-arginine, $20 \mu \mathrm{g} / \mathrm{ml}$ L-aspartic acid (LifeTechnologies Inc., Grand Island, N ew York, USA), $50 \mu \mathrm{M}$ 2-M ercaptoethanol (Sigma Chemical Co.), 5 $\mu \mathrm{g} / \mathrm{ml}$ penicillin and $100 \mathrm{U} / \mathrm{ml}$ streptomycin (Life Technologies Inc.), and 5\%autologous human serum or plasma. Azide-free preparations of murine antihuman HLA-DQ (SPV-L3) and HLA-DR (LN3) mAb's (N eomarkers Inc., Fremont, California, USA) and isotype-matched control mAb's were used at an optimal concentration $(20 \mu \mathrm{g} / \mathrm{ml})$.

Generation of short-term insulin $\mathrm{B}_{(9-23)}$-specific $\mathrm{T}$-cell linesfrom peripheral blood. PBM Cs from all subjects wereisolated by centrifugation through Ficoll-Hypaquedensity gradients (Vacutainer CPT; Becton Dickinson Labware, Lincoln Park, N ew Jersey, USA), and lymphocytes were washed and either stimulated with $\mathrm{B}_{(9-23)}$ peptide to generate Tcell lines or stored frozen in aliquots for futureevaluation of cytokine production using theELISPOT assay. Insulin $\mathrm{B}_{(9-23)}$-specific T-cell lines weregenerated by culturing $5 \times$ $10^{6}$ purified PBM Cs per well of a 24-well culture plate (Falcon; Becton Dickinson Labware) in thepresence of 10 $\mu \mathrm{M}$ insulin $\mathrm{B}_{(9-23)}$ for $7-10$ days. After washing, $3 \times 10^{6} \mathrm{~T}$ cells were restimulated in $25 \mathrm{~cm}^{2}$ tissue culture flasks with $6 \times 10^{5}$ irradiated ( $30 \mathrm{~Gy}$ ) autologous PBMCs as antigen presenting cells (1:5 ratio of antigen-presenting cells/T cells) in the presence of $B(9-23)$ peptide $(10 \mu \mathrm{M})$ and recombinant human IL-2 (5 U/ml; Boehringer M annheim, Germany) for another 7-10 days. After an additional stimulation cycle, lymphocytes were used in proliferation assays. Autologous PBM Cs used for restimulation of T-cell lines werestored frozen until use.

\section{Table 3}

Serum autoantibody levels to islet autoantigens in type 1 diabetic patients and prediabetic individuals at high risk for diabetes

Patient ID

\begin{tabular}{|c|c|c|}
\hline Serum leve & anti- $\beta$-islet & ies $^{A}$ \\
\hline Anti-IA-2 & Anti-GAD 65 & Anti-insulin \\
\hline-0.045 & $0.295^{B}$ & $0.028^{B}$ \\
\hline-0.048 & $0.086^{\mathrm{B}}$ & -0.004 \\
\hline-0.041 & $0.165^{\mathrm{B}}$ & 0 \\
\hline $0.364^{\mathrm{B}}$ & $0.09^{B}$ & 0.006 \\
\hline 0.923 & $0.581^{\mathrm{B}}$ & 0.003 \\
\hline-0.045 & -0.002 & 0 \\
\hline-0.043 & -0.019 & 0.003 \\
\hline $0.477^{\mathrm{B}}$ & $1.019^{\mathrm{B}}$ & 0.837 в \\
\hline $0.784^{B}$ & $0.042^{B}$ & 0.003 \\
\hline-0.035 & $0.128^{B}$ & \\
\hline-0.005 & $0.27^{\mathrm{B}}$ & -0.003 \\
\hline $0.103^{B}$ & $0.083^{B}$ & -0.002 \\
\hline 0.044 & $1.061^{\mathrm{B}}$ & -0.007 \\
\hline-0.009 & -0.024 & 0.002 \\
\hline 0.009 & $0.866^{B}$ & $0.012^{B}$ \\
\hline-0.003 & -0.006 & $0.281^{\mathrm{B}}$ \\
\hline
\end{tabular}

ASerum levels of anti-GAD65 and anti-IA-2 antibody from type 1 diabetic patients $(\mathrm{P \#})$ and prediabetic individuals at high risk for diabetes who have not received insulin therapy $(\mathrm{H} \#)$ were measured by a liquid-phase competitive RIA and anti-insulin levels were measured by a protein A microassay. Positive and negative control sera were included that were used to calculate an index for antibody levels as described by the following equation: (unknown sample valuenegative control value)/(positive control value - negative control value). The upper normal limit for each autoantibody was established as three times the 100th percentile in 241 healthy controls using the Receiver O perator Curve analysis. BSera were considered positive for the respective antibodies at the following index values: $>0.071$ for IA-2, $>0.032$ for GAD 65, and $>0.01$ for insulin. 


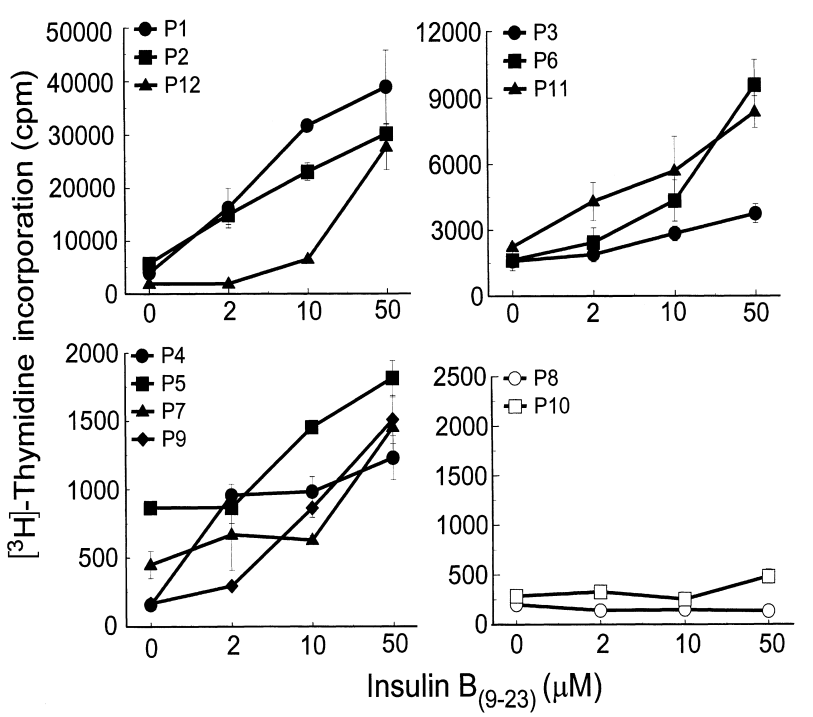

Figure 1

Type 1 diabetic patient response to insulin $B_{(9-23)}$ peptide. $A$ total of $10^{5} \mathrm{~T}$ lymphocytes from short-term cell lines of $B_{(9-23)}$-treated PBM Cs from type 1 diabetic patients (i.e., P1-P12) were seeded per well of a 96 -well round-bottom plate with $7 \times 10^{4}$ irradiated autologous PBM Cs in the presence or absence of different concentrations of insulin $\mathrm{B}_{(9-23)}$ peptide. Cells were cultured for 5 days in which each well was pulsed with $\left[{ }^{3} \mathrm{H}\right]$ thymidine for the final $18-20$ hours, and the amount of incorporated radioactivity was counted. Values in all panels are the mean cpm \pm SEM of triplicate cultures from one experiment representative of at least two experiments for all patients.

T lymphocyte-proliferation assay. A total of $10^{5} \mathrm{~T}$ lymphocytes from cell lines werecultured in 96-well roundbottom plates (Costar; Corning Inc., Corning, N ew York, USA) with $7 \times 10^{4}$ irradiated autologous PBM Cs (optimal cell number) in the presenceor absence of different concentrations of insulin $\mathrm{B}_{(9-23)}$ peptideor phytohemagglutinin (PHA-M ; L8902; Sigma Chemical Co.). Cells were cultured at $37^{\circ} \mathrm{C}, 7.5 \% \mathrm{CO}_{2}$ atmosphere in a humidified incubator for 5 days, and each well was pulsed with $1 \mu \mathrm{Ci}$ tritiated thymidine $([3 \mathrm{H}] \mathrm{TdR}$; sp. act. $25 \mathrm{Ci} / \mathrm{mmol}$; Amersham LifeScience, Arlington H eights, Illinois, USA) for the final 18-20 hours. Cells were harvested onto glass fiber-lined plates (Unifilter-96 GF/B; Packard Instrument Co., M eriden, Connecticut, USA) and the amount of radioactivity incorporated into de novo synthesized DNA was measured in a scintillation counter (Top Count NXT; Packard Instrument Co.).

ELISPOT assay. The number of cytokine-expressing cells in PBM Cs from control subjects and type 1 diabetic patients was quantified by the ELISPOT assay as described elsewhere (25). Briefly, $3 \times 10^{5}$ PBMCs obtained from frozen aliquots were seeded per well of 96-well plates coated with anti-human IFN $-\gamma$ mAb (Endogen Inc., Cambridge, M assachusetts, USA) or other anti-cytokinemAb (PharM ingen Inc., San Diego, California, USA) in the presence or absence of either $\mathrm{B}_{(9-23)}$ peptide, tetanus toxoid (Accurate Chemical \& Scientific Corp., Westbury, N ew York, USA), or PHA (Sigma Chemical Co.). After 24 to 48 hours of incuba- tion at $37^{\circ} \mathrm{C}, 5 \% \mathrm{CO}_{2}$, cells were washed away and cytokines were detected with anti-human IFN $-\gamma$ (Endogen Inc.) or anti-human IL-2, IL-4, IL-5, or IL-13 (PharM ingen Inc.) secondary biotinylated-mAb plus avidin-peroxidase. AEC substrate solution (3-amino-9ethyl carbazole; PierceChemical Co., Rockford, Illinois, USA) was used to develop the reaction, which was stopped by washing the plate with water. Spots derived from cytokine-producing cells were quantified using the Series-1 Immunospot and Satellite Analyzers (Autoimmun Diagnostika Inc., Strassberg, Germany). Purified HLA-DQ bindingassay. Peptidebinding to HLADQA1*0301/DQB1*0302 (HLA-DQ8) was assessed using a competitive inhibition Europium fluorometric assay as described previously (26). The $50 \%$ inhibitory concentrations $\left(\mathrm{IC}_{50}\right)$ werecal culated from competitive inhibition displacement curves for each peptide and wereused as estimates of thepeptide-binding affinities to the HLA-DQ 8 molecules.

\section{Results}

Insulin $\mathrm{B}_{(9-23)}$-proliferativeresponse of PBM Csfrom patientswith recent-onset type 1 diabetes. The $B_{(9-23)}$ epitope of insulin appears to be an immunodominant target antigen in NOD mice (4-7). Weinvestigated whether this epitope also played a rolein human type 1 diabetes by determining whether cellular responses to insulin $\mathrm{B}_{(9-23)}$ had developed in peripheral blood lymphocytes from type 1 dia-

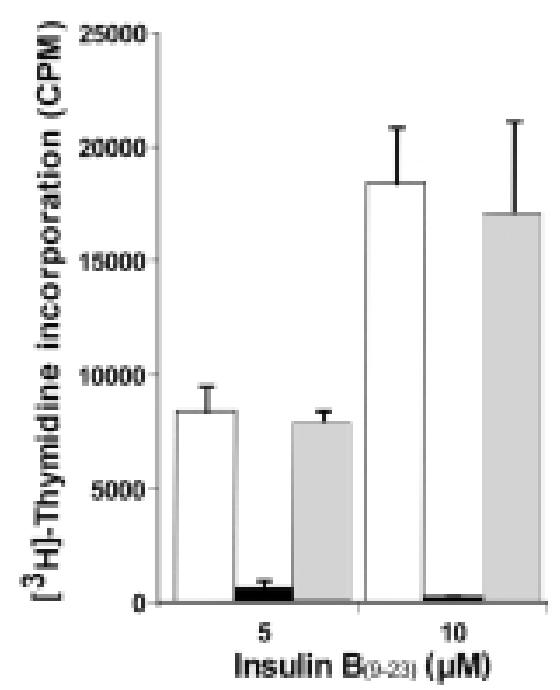

Figure 2

Role of HLA-DQ 8 in insulin B(9-23)-specific response in a type 1 diabetic patient. A total of $10^{5} \mathrm{~T}$ lymphocytes from short-term cell lines of $B$ (9-23)-treated PBM Cs from type 1 diabetic patient $P 2$, homozygous for HLA-DR4 (DRB1*0402/0405) and DQ 8 (DQB1*0302), were treated in the presence or absence of $20 \mu \mathrm{g} / \mathrm{ml}$ anti-DQ or anti-DR blocking antibody. These antibodies were added to stimulator autologous PBM Cs 30 minutes before responder T cells were added. Cells were cultured for 5 days during which each well was pulsed with $\left[{ }^{3} \mathrm{H}\right]$ thymidine for the final 18-20 hours and the amount of incorporated radioactivity was counted. Isotype control antibody had no significant effect on proliferation. Values are the mean $\mathrm{cpm} \pm \mathrm{SEM}$ of triplicate cultures from one experiment representative of three experiments. 
betic patients. Short-term T-cell lines from 12 recentonset type 1 diabetic patients and from 13 nondiabetic HLA- or age-matched normal control subjects (C1-C13) and one high-risk first-degree relative (H5) were challenged with insulin $\mathrm{B}_{(9-23)}$, and proliferation was assessed. Theseshort-term cell lines weregenerated to increasethe frequency of any $\mathrm{B}_{(9-23)}$-specific $\mathrm{T}$ cells beforeproliferation assays because frequencies of antigen-specific $T$ cells in freshly isolated PBM Cs areusually low. Ten of 12 diabetic patients responded to $B_{(9-23)}$ in a dosedependent manner (Figure 1) and to different degrees (Table 4; mean \pm SEM of stimulation index [SI, as described in legend to Table 4] $=6.4 \pm 1.2$ ), whereas the response was absent in all nondiabetic control subjects (Table4; mean \pm SEM of $\mathrm{SI}=1.1 \pm 0.1)$. An SI greater than 2 was considered positive. N otethat the comparison of control-patient siblingmatches (i.e., $\mathrm{C} 11$ and $\mathrm{P} 1 ; \mathrm{C} 12, \mathrm{C} 13$, and $\mathrm{P} 2$; and $\mathrm{H} 5$ and $\mathrm{P} 12$ ) and HLA-matches ( $\mathrm{C} 5$ and $\mathrm{P} 9 ; \mathrm{C} 11$ and $\mathrm{P} 1, \mathrm{P} 2$; and $\mathrm{H} 5$ and $\mathrm{P} 11, \mathrm{P} 12)$ underscores thestriking association of this $\mathrm{B}_{(9-23)}$-response specifically with the type 1 diabetes group. In some cases with control subject cultures, cell viability appeared to decrease dramatically after the first restimulation cycle, in which case assays were performed after thefirst stimulation cycle. Lack of responsiveness by control subjects or by the two patients (i.e., P8 and P10) was not attributed to cell death because these individuals responded to the T-cell mitogen, $\mathrm{PHA}$ (Table4). Additionally, $\mathrm{B}_{(9-23)}$ responsiveness was specific becausethesepatients did not respond to unrelated control peptides (data not shown). Theseresults demonstratethat themajority ( $83 \%$ ) of diabetic patients, but not H LA- or age-matched control subjects, developed a proliferative responseto theinsulin $\mathrm{B}_{(9-23)}$ peptide.

Insulin $\mathrm{B}_{(9-23)}$ peptide presentation by HLA class II molecules. Insulin $\mathrm{B}_{(9-23)}$ is an HLA class II-restricted immunodominant epitope for pathogenic CD 4+ $T$ cells isolated from the pancreata of young NOD mice (4-6). To confirm that the $\mathrm{B}_{(9-23)}$-response in type 1 diabetic patients is class II restricted, $T$ lymphocytes from $B_{(9-23)}$-reactive cell lines from patient $P 2$, who is homozygous for H LA-D R4 (DRB1*0402/0405) and DQ 8 (DQB1*0302) alleles, werechallenged with $B(9-23)$ in the presence or absence of antibodies to DR or DQ molecules, and proliferation was assessed (Figure2). T lymphocytes from patient $P 2$ were used because the $B_{(9-23)}$ peptide has been shown to bind HLA-DQ 8 (D QB1*0302) molecules (26), a haplotype that is among the most strongly associated with, and predictive of, human disease $(1,27)$. The H LADQB1*0302 allele also displays a nonaspartic acid (i.e., alanine) residue in its $\beta$ chain at position 57 , a residuethat is al so characteristic of the unique disease-associated I-A ${ }^{7} \mathrm{M} \mathrm{HC}$ haplotype in the N OD mouse (28). Only blockade of DQ molecules during $\mathrm{B}_{(9-23)}$ presentation complete- ly inhibited proliferation of theshort-term cell linegenerated from this individual (Figure 2), demonstrating that the disease-associated response to $B_{(9-23)}$ is $H L A$ class II restricted and, in this patient, is restricted to the HLA-DQ8, and not to the DR4, molecule. We also determined the affinity of binding of the $B_{(9-23)}$ peptide to the DQ 8 molecule in a competitive displacement binding assay, in which the $B_{(9-23)}$ peptide was evaluated for its ability to competewith thestandard high-affinity peptide, biotinyl-(HSV-2)-VP16, for binding to the HLA-DQ 8 molecule. $B_{(9-23)}$ efficiently competed for binding to HLA-DQ 8 with a binding affinity $\left(I C_{50}\right.$ value of $0.4 \mu \mathrm{M}$ ) very similar to the unlabel ed (HSV-2)-VP16 peptide $\left(I C_{50} 0.37 \mu \mathrm{M}\right)$. A noncompetitive control peptide, $\mathrm{SWM}_{(110-121)}$, had an $\mathrm{IC}_{50}$ of greater than $100 \mu \mathrm{M}$.

Cytokine response by $B_{(9-23)}$-specific primary PBM Cs. The strong $\mathrm{B}_{(9-23)}$-specific proliferativeresponse of $\mathrm{T}$-cell lines from type 1 diabetic patients suggests that a substantial number of pathogenic (i.e., IFN- $\gamma$ producing) $B_{(9-23)-S p e}$ cific $T$ cells exist in the circulation of these patients. We

\section{Table 4}

Proliferative response of type 1 diabetes patients and normal nondiabetic control subjects to insulin $\mathrm{B}_{(9-23)^{\mathrm{A}}}$

Type 1 diabetic patients Subject ID Medium alone Insulin $\mathrm{B}_{(9-23)} \quad \mathrm{SI}^{\mathrm{B}} \quad \mathrm{PHA}$
$\left[{ }^{3} \mathrm{H}\right]$ thymidine incorporation
(mean cpm $\pm \mathrm{SEM})$

$\begin{array}{lc}\text { P1 } & 3,924 \pm 340 \\ \text { P2 } & 5,739 \pm 634 \\ \text { P3 } & 1,588 \pm 230 \\ \text { P4 } & 158 \pm 12 \\ \text { P5 } & 867 \pm 29 \\ \text { P6 } & 1,636 \pm 475 \\ \text { P7 } & 451 \pm 100 \\ \text { P8 } & 199 \pm 46 \\ \text { P9 } & 168 \pm 18 \\ \text { P10 } & 286 \pm 34 \\ \text { P11 } & 2,240 \pm 200 \\ \text { P12 } & 1,921 \pm 400\end{array}$

$\begin{array}{cr}38,935 \pm 6,856^{A} & 9.9 \\ 30,184 \pm 1,776^{A} & 5.3 \\ 3,742 \pm 429^{A} & 2.3 \\ 1,230 \pm 161^{A} & 7.8 \\ 1,815 \pm 129^{A} & 2.1 \\ 9,566 \pm 1,146^{A} & 5.8 \\ 1,455 \pm 219^{A} & 3.2 \\ 133 \pm 11 & 0.6 \\ 1,510 \pm 176^{A} & 8.9 \\ 483 \pm 73 & 1.6 \\ 8,357 \pm 716^{A} & 3.7 \\ 27,709 \pm 4,326^{A} & 14.4\end{array}$

$167,946 \pm 7,596$ ND ND $119,431 \pm 7,276$ $95,679 \pm 2,397$ $111,777 \pm 7,368$ $127,905 \pm 2,136$ $171,143 \pm 8,571$

$63,994 \pm 1,912$ $297,387 \pm 9,820$ $151,851 \pm 1,673$

$78,385 \pm 4,169$

Nondiabetic controls

$\begin{array}{lcccc}\text { C1 } & 1,598 \pm 183 & 1,828 \pm 223 & 1.1 & 81,074 \pm 1,743 \\ \text { C2 } & 2,366 \pm 436 & 4,229 \pm 966 & 1.8 & 39,934 \pm 2,288 \\ \text { C3 } & 431 \pm 31 & 645 \pm 106 & 1.5 & 6,456 \pm 222 \\ \text { C4 } & 659 \pm 122 & 1,098 \pm 161 & 1.7 & 8,869 \pm 537 \\ \text { C5 } & 6,609 \pm 765 & 6,198 \pm 932 & 0.9 & 50,519 \pm 1,081 \\ \text { C6 } & 1,161 \pm 292 & 1,622 \pm 1287 & 1.4 & 12,154 \pm 540 \\ \text { C7 } & 7,922 \pm 381 & 8,780 \pm 681 & 1.1 & 19,603 \pm 635 \\ \text { C8 } & 2,690 \pm 256 & 1,190 \pm 7 & 0.4 & 24,736 \pm 2,635 \\ \text { C9 } & 2,707 \pm 758 & 2,036 \pm 355 & 0.8 & 18,058 \pm 796 \\ \text { C10 } & 3,709 \pm 344 & 3,861 \pm 991 & 1 & 29,039 \pm 1,171 \\ \text { C11 } & 287 \pm 68 & 399 \pm 152 & 1.4 & 92,718 \pm 2,729 \\ \text { C12 } & 3,206 \pm 413 & 2,248 \pm 291 & 0.7 & 77,964 \pm 3,014 \\ \text { C13 } & 989 \pm 281 & 1,017 \pm 57 & 1 & 54,057 \pm 5,074\end{array}$

High-risk subject
$\mathrm{H} 5$
$211 \pm 30$
$219 \pm 30$
1
$50,168 \pm 5,585$

AA total of $10^{5}$ lymphocytes from short-term $B_{(9-23)}$-derived PBM C lines from type 1 diabetic patients $(P \#)$, normal nondiabetic control subjects $(C \#)$, and individuals at high risk for diabetes who have not received insulin therapy $(\mathrm{H} \#)$ were cultured with $7 \times 10^{4}$ irradiated autologous PBM Cs in the presence or absence of insulin $B_{(9-23)}$ peptide ( 50 $\mu \mathrm{M})$ or the T-cell mitogen, PHA $(10 \mu \mathrm{M})$. Cells were cultured for 5 days during which each well was pulsed with $\left[{ }^{3} \mathrm{H}\right]$ thymidine for the final $18-20$ hours the amount of incorporated radioactivity was counted. Values are the mean cpm and SEM of triplicate cultures from one experiment representative of at least three experiments per subject. ${ }^{A}$ Significantly $(P<0.05)$ different from mean values of unstimulated cultures. ${ }^{B}$ Stimulation Index $(\mathrm{SI})=\left(\mathrm{B}_{(9-23)}\right.$-stimulated mean $\left.\mathrm{cpm}\right) /$ (unstimulated mean $\left.\mathrm{cpm}\right)$. 


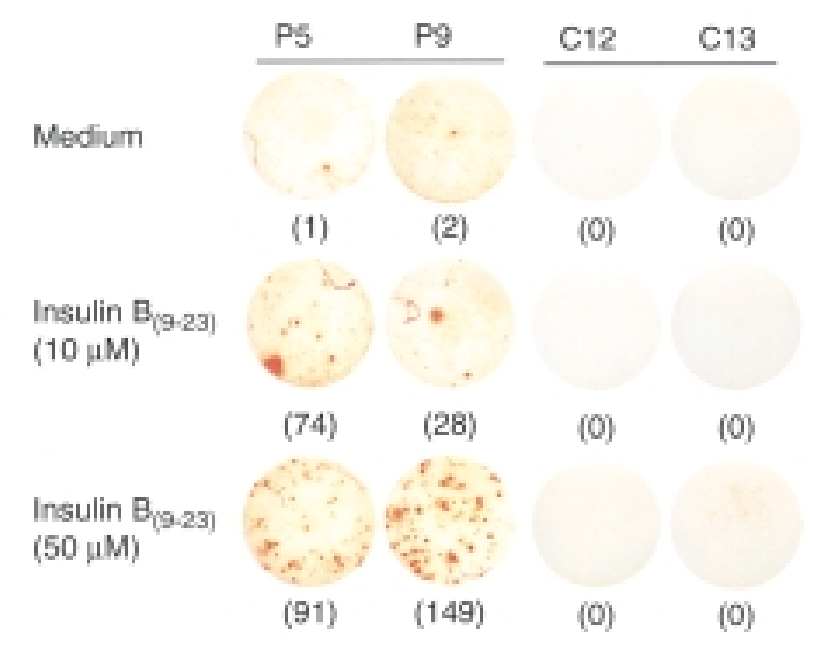

Figure 3

Example of cytokine responses to insulin $B_{(9-23)}$ by type 1 diabetic patients and control subjects. $3 \times 10^{5}$ freshly isolated PBM Cs from two type 1 diabetic patients (P5 and P9) and two age-matched control subjects ( $\mathrm{C} 12$ and $\mathrm{C} 13$ ) were seeded per well of a 96 -well anti-IFN $-\gamma$ mAb-coated ELISPOT assay plate in the presence or absence of insulin $\mathrm{B}_{(9-23)}$ and incubated at $37^{\circ} \mathrm{C}$ for 24 hours. Spots representing IFN $-\gamma$-producing cells (denoted by the number in parentheses) were developed using a biotinylated anti-IFN - $\gamma$ secondary antibody and avidin-labeled peroxidase with AEC substrate and quantified using the Series-1 Immunospot Analyzer.

therefore estimated thefrequency and assessed cytokine production of these $B_{(9-23)}$-specific cells in freshly isolated PBM Cs using theELISPOT assay. This techniquehas uniqueadvantages over other cytokine detection assays in that it displays an extremely high degree of sensitivity and can beused to quantify the number of antigen-specific cytokineproducing cells in a heterogeneous T-cell receptor population (25). PBM Cs were obtained from diabetic patients and control subjects and presented with $\mathrm{B}_{(9-23)}$ or the positive control mitogen, PHA, on ELISPOT plates for assessment of cytokines. IL-2-, IL-4-, IL-5-, or IL-13-producing cells werenot detected in either untreated or $\mathrm{B}_{(9-23)}$-treated PBMC cultures from nondiabetic (including high-risk) control or diabetic subjects (data not shown); however, activation of cultures with PH A demonstrated theappearance of thesecytokineproducing cells (data not shown). In contrast, treatment with a high dose $(50 \mu \mathrm{M})$ of $\mathrm{B}_{(9-23)}$ induced substantial numbers of IFN $-\gamma$-producing cells in PBM C cultures from all but one diabetic patient tested (i.e., P8), whereas all of the nondiabetic control subjects studied werenonresponsive to $B_{(9-23)}$ treatment (Table 5; the mean and SEM of the $\mathrm{B}_{(9-23)}$-induced change [i.e., $\left.\mathrm{SI}\right]$ in the number of IFN$\gamma$-producing cells in control cultures $\mathrm{C} 1-\mathrm{C} 26$ was $1.11 \pm$ 0.2). Samplesfrom $\mathrm{C} 12$ and $\mathrm{C} 13$ were included in Table 5 as examples of nonresponders. Blood samples from diabetic patients $\mathrm{P} 1, \mathrm{P} 3, \mathrm{P} 6$, and $\mathrm{P} 12$ and control subjects $\mathrm{C} 5$, $\mathrm{C} 9$, and $\mathrm{C} 11$ werenot availablefor cytokineanalysis. Type 1 diabetic patients responded in a dose-dependent manner to $B_{(9-23)}$ because a significant number of cytokine- positive cells wereinduced with a $10 \mu \mathrm{M} \mathrm{B}_{(9-23)}$ dose (see Figure 3 for an example of 10 and $50 \mu \mathrm{M} \mathrm{B}_{(9-23)}$-induced IFN- $\gamma$-specific spots). Lack of response in nondiabetic control samples (i.e., C\#), and that of patient P8 and the high-risk subjects, $\mathrm{H} 3$ and $\mathrm{H} 4$, was not attributed to a general anergy of the cells because cells from these subjects, in addition to those of all diabetic patients (Table 5), responded to treatment with PHA (the mean and SEM of thePHA-induced changein the number of IFN $\gamma$-producing cells in nondiabetic control cultures $\mathrm{C} 1$ through $\mathrm{C} 26$ was $17 \pm 8$ ).

We addressed the possibility that insulin therapy could be responsible for the $\mathrm{B}_{(9-23)}$-specific responses observed. N otethat all type 1 diabetics received insulin therapy during a brief period before blood sampling (i.e., 2-127 days), in which P9 and P10 were sampled only 2 days after insulin therapy. This brief 2-day period is not likely to besufficient for an immune response to develop against exogenous insulin. In addition, the two type 2 diabetics, C27 and C28, who had received insulin therapy for 5 and 20 years, respectively, did not respond to $B_{(9-23)}$ at $50 \mu \mathrm{M}$ (the mean and SE of $B_{(9-23)^{-}}$ induced change in IFN- $\gamma$-producing cells was $0.65 \pm$ 0.22 and $1.02 \pm 0.11$, respectively, and that for PHA was $179 \pm 17$ and $49 \pm 1$, respectively). However, the most compelling evidence that insulin therapy did not play a rolein the development of $B_{(9-23)}$ responses in diabetics was demonstrated by the reactivity to $\mathrm{B}_{(9-23)}$ by three of five prediabetic high-risk first-degree relatives who never received insulin therapy (Table5).

Interestingly, one (i.e., P10) of the two patients that did not display a proliferative response to $\mathrm{B}_{(9-23)}$ (seeTable 4 and Figure 1) showed a strong IFN- $\gamma$-production response to theantigen (Table5), suggesting that antigenspecific responses in cytokine production are not necessarily accompanied by proliferativeresponses. Accordingly, $\mathrm{B}_{(9-23)}$-induced IFN- $\gamma$ production by the high-risk first-degreerelative, H5 (Table 5), al so was not accompanied by a proliferativeresponse(seeTable4 and Figure1). Consistent with results of T-cell line proliferation, these results demonstratethat the $B_{(9-23)}$-specific IFN $-\gamma$ response is limited to type 1 diabetic patients and to high-risk prediabetic individuals. In addition, $\mathrm{B}_{(9-23)}$-specific $\mathrm{T}$ cells were of thepathogenic phenotype, as was previously def ined in theNOD mouseand, most importantly, can be detected directly in the circulation using theELISPOT assay.

\section{Discussion}

Consistent with thenature of autoantigenic epitopes in the pancreas of NOD mice (4-7), we found substantial $\mathrm{T}$-cell responses to the $\mathrm{B}_{(9-23)}$ immunodominant epitope of insulin in peripheral blood of $92 \%$ (11 of 12 ; i.e., proliferative and cytokine responses) of the recent-onset type 1 diabetic patients examined, but such responses were absent in age or HLA-matched nondiabetic normal control subjects. These anti-insulin $B_{(9-23)} T$ cell responses are not likely to be a result of immunoreactivity to insulin therapy becausewedid not detect T-cell responses to $\mathrm{B}_{(9-23)}$ in the type 2 diabetic control group 
that received insulin therapy. In addition, these $\mathrm{B}_{(9-23)} \mathrm{T}$ cell responses were present in samples from patients $P 9$ and P10 only 2 days after thestart of insulin therapy (all other patient samples wereobtained 2 to 10 weeks after insulin therapy). M ost importantly, three of five prediabetic high-risk individuals who never received insulin therapy responded to $\mathrm{B}_{(9-23)}$ in the ELISPOT assay.

It has been previously reported that despitestatistically significant differences between control subjects and recent-onset type 1 diabetic patients in cellular responsiveness to $\beta C A$ s, such as GAD, most control subjects, in fact, respond to the autoantigens, al beit to a lesser degree than do patients with type 1 diabetes $(12-16,29)$. Interestingly, thesestudies al so demonstrated that the degree and frequency of responses to thewholeinsulin or proinsulin proteins were comparable among controls, recentonset diabetic patients, and their relatives, arguing against theexistence of pronounced cellular responses to insulin in typel diabetes. However, by analyzing responses to a single insulin epitope [i.e., $\mathrm{B}_{(9-23)}$ that appears to play astrong pathogenic rolein the N OD mousedisease, wedemonstratehere, for thefirst timeto our knowledge, that control subjects wereclearly unresponsiveto the $B_{(9}$. 23), which is contrasted with an almost completeresponsiveness by thetype 1 diabetic patient group and with a responsiveness in over half of the high-risk first-degree relativesubjects studied. In fact, thefrequency of thecellular responseto $\mathrm{B}_{(9-23)}$ in these groups was greater than that of the antibody response to any single pancreatic antigen. Our findings with the high-risk first-degreerelativegroup areconsistent with another study that shows reactivity to another insul in epitope, amino acid 24-36 of proinsulin, which is confined to first-degree relatives of type 1 diabetics (29). Indeed, the presence of circulating $\mathrm{B}_{(9-23)}$-responsive $T$ cells in recent-onset diabetics was confirmed using the ELISPOT assay in which IFN $-\gamma$-producing $B_{(9-23)}$-responsive peripheral blood cells were detected after 12 days of in vitro culturing in the presence of antigen. These results demonstrate that there is not only a strong specific responseto an insulin epitopein human type1 diabetes, but that this responseis confined to the prediabetic and new-onset diabetic groups and, therefore, may becharacteristic of thehuman disease.

We used the ELISPOT assay to analyze the quality and quantity of the $B_{(9-23)}$ response in freshly isolated PBM Cs (25), in contrast to enriching for $B_{(9-23)}$ specificity in cell lines for proliferation assays. Thehigh sensitivity of theELISPOT assay for detection of cytokineproducing cells enabled the quantification of the low-frequency of $\mathrm{B}_{(9-23)}$-reactive cells in freshly isolated PBM Cs from type 1 diabetic patients, especially in cases in which $\mathrm{B}_{(9-23)}$ failed to generate $\mathrm{T}$-cell lines (i.e., $\mathrm{H} 5$ and P10). Indeed, ELISPOT detection of a cytokine response to $B_{(9-23)}$ by some of the subjects in the prediabetic first-degree relativegroup has implications for a novel diagnostic approach.

Similar to theassociation of someHLA alleles with type 1 diabetes (27), humoral responses to $\beta C A$ s, which are usually elevated in prediabetic and recent-onset type 1 dia-

\section{Table 5}

ELISPOT analysis of IFN- $\gamma$ production response to insulin $B_{(9-23)}$ in type 1 diabetic patients, prediabetic individuals at high risk, and normal nondiabetic control subjects

\begin{tabular}{|c|c|c|c|}
\hline \multirow[t]{2}{*}{ Subject ID } & \multicolumn{3}{|c|}{ Antigen addition to freshly isolated PBM CsA } \\
\hline & $\begin{array}{l}\text { None } \\
\quad \text { (IFN-? }\end{array}$ & $\begin{array}{l}\text { insulin } B_{(9-23)} \\
\text { ng cells per }\end{array}$ & $\begin{array}{r}\text { PHA } \\
\text { ר SEM ) }\end{array}$ \\
\hline $\begin{array}{l}\text { P2 } \\
\text { P4 } \\
\text { P5 } \\
\text { P7 } \\
\text { P8 } \\
\text { P9 } \\
\text { P10 } \\
\text { P11 } \\
\text { H1 } \\
\text { H2 } \\
\text { H3 } \\
\text { H4 } \\
\text { H5 } \\
\text { C12 }\end{array}$ & $\begin{aligned} 0.5 & \pm 0.5 \\
1 & \pm 1 \\
3 & \pm 1 \\
47 & \pm 35 \\
22 & \pm 10 \\
10 & \pm 0.5 \\
41 & \pm 40 \\
65 & \pm 20 \\
7 & \pm 3 \\
16 & \pm 2 \\
7 & \pm 2 \\
21 & \pm 7 \\
5 & \pm 2.6 \\
1.3 & \pm 0.3 \\
3 & \pm 1\end{aligned}$ & $\begin{aligned} 227 & \pm 34^{\mathrm{B}} \\
302 & \pm 96^{\mathrm{B}} \\
33 & \pm 3^{\mathrm{B}} \\
217 & \pm 4^{\mathrm{B}} \\
11 & \pm 2 \\
123 & \pm 1^{\mathrm{B}} \\
683 & \pm 221^{\mathrm{B}} \\
844 & \pm 199^{\mathrm{B}} \\
59 & \pm 26^{\mathrm{B}} \\
81 & \pm 12^{\mathrm{B}} \\
12 & \pm 4 \\
43 & \pm 10 \\
162 & \pm 65^{\mathrm{B}} \\
1.7 & \pm 1.2 \\
1.3 & \pm 0.9\end{aligned}$ & $\begin{array}{c}240 \pm 25^{B} \\
706 \pm 20^{B} \\
\text { TNTCB } \\
\text { TNTC } \\
610 \pm 16^{B} \\
\text { BNTCB }^{B} \\
655 \pm 70^{B} \\
\text { TNTCB } \\
509 \pm 59^{B} \\
1002 \pm 23^{B} \\
291 \pm 35^{B} \\
672 \pm 47^{B} \\
450 \pm 10^{B} \\
1,780 \pm 60^{B} \\
810 \pm 20^{B}\end{array}$ \\
\hline
\end{tabular}

$\mathrm{A} 3 \times 10^{5}$ freshly isolated PBM C from eight type 1 diabetic patients (P\#), five pre diabetic individuals at high risk for diabetes who have not received insulin therapy $(\mathrm{H \#})$, and three normal nondiabetic control subjects ( $\mathrm{C \# )}$ were seeded per well in triplicate or quadruplicate in 96-well anti-IFN- $\gamma$ mAb-coated ELISPOT assay plates in the presence or absence of insulin $\mathrm{B}_{(9-23)}(50 \mu \mathrm{M})$ or $\mathrm{PHA}(10 \mu \mathrm{M})$ and incubated at $37^{\circ} \mathrm{C}$ for 24 hours. Spots representing IFN- $\gamma$-producing cells were developed using a biotinylated anti-IFN- $\gamma$ secondary antibody and avidinlabeled peroxidase with AEC substrate and quantified using the Series-1 Immunospot Analyzer. Results are from one experiment representative of at least two experiments per subject. BSignificantly different $(P<0.05)$ from mean values of unstimulated control cultures. TNTC, too numerous to count.

betes individuals $(1,10)$, are also predictive of disease. Although it might be expected that both cellular and humoral responses to a particular $\beta C A$ would beelevated during diabetes, several groups have reported an inverse relationship between cellular and humoral responses to $\beta C A s(15,30)$, including those to thewhole-insulin protein (12). Interestingly, patient P8, who did not show aceIular (i.e, proliferative or cytokine-production) response to $\mathrm{B}_{(9-23)}$ (seeTables 4 and 5; Figure 1), was theonly patient that demonstrated a dramatic endogenous anti-insulin antibody responsein addition to showing substantial antiGAD 65 and anti-IA-2 antibody responses (see Table 3). Conversely, all other patients demonstrated strong cellular responses to $\mathrm{B}_{(9-23)}$, with little or no humoral response to insulin. To date, themechanism underlying this inverse relationship remains elusive; however, this dichotomy is consistent with thenature of normal immuneresponses to antigen, which tend to beskewed toward either cellularpromoting (IFN- $\gamma$-producing) or humoral-promoting (non-IFN- $\gamma$-producing) immuneresponses (31).

Because type 1 diabetes is primarily mediated by destructivecellular immuneresponses to $\beta C A$ s, thelack of a cellular $B_{(9-23)}$ response by patient P8 suggests that responses to other $\beta C A$ s or other epitopes of insulin play a dominant pathogenic rolein this patient. Indeed, the MHC haplotype of patient P8, who lacks HLADQB1*0302 expression, may not be ableto present the $B_{(9-23)}$ peptide to autoreactive T cells. Alternatively, this unresponsiveness may bea result of reduced antigen [i.e., insulin $\mathrm{B}_{(9-23)}$ ] concentration in this patient that aroseas 
a consequence of substantial islet $\beta$-cell damage, as has been observed in the NOD mouse $(4,6,7)$.

Given the nature of this disease, direct evidence for the role of $B_{(9-23)}$ responsive cells in the pathogenesis of diabetes can only be addressed using animal models. Using the NOD mouse model, Wegmann and his colleagues have convincingly demonstrated that $\mathrm{B}_{(9-23)}$-reactive $\mathrm{CD} 4^{+} \mathrm{T}$ hel per cells are involved in the destruction of the $\beta$-islet cells (4-6). In addition, Wong et al. (7), using a fluorescent-label ed M HC class I tetrameric complex bound to the $\mathrm{B}_{(15-23)}$ peptide, demonstrated that greater than $80 \%$ of $C D 8^{+} T$ cells infiltrating islets of 4-week-old NOD mice (well beforeany clinical evidence of disease) recognized the $B_{(15-23)}$ epitope. M oreover, disease is prevented when thymic deletion of anti-insulin T cells is induced in transgenic NOD micewith targeted expression of the proinsulin genein antigen-presenting cells under the control of the M HC class II promoter (32). These data and our human subject studies reported herein strongly suggest that this region of the $B$ chain of insulin is a target of the immune system in this autoimmune disease. Thus, therapies that are directed at this autoantigenic response might be of benefit in controlling type 1 diabetes, which is supported by studies that show administration of the $B$ chain or $B_{(10-24)}$ peptide of insulin induce a protective Th2 immuneresponse in NOD mice $(6,33,34)$.

\section{Acknowledgments}

The authors thank George Eisenbarth (Barbara Davis Center for Childhood Diabetes) for his critical review of themanuscript.

1. Atkinson, M .A., and M aclaren, N.K. 1994. The pathogenesis of insulindependent diabetes mellitus. N . Engl. J. M ed. 331:1428-1436.

2. Delovitch, T.L., and Singh, B. 1997. The nonobese diabetic mouse as a model of autoimmune diabetes: immune dysregulation gets the NOD [erratum 1998, 8:531]. Immunity. 7:727-738.

3. Durinovic-Bello, I. 1998. Autoimmune diabetes: the role of T cells, M HC molecules and autoantigens. Autoimmunity. 27:159-177.

4. Wegmann, D.R., N orbury-Glaser, M ., and Daniel, D . 1994. Insulin-specific $T$ cells area predominant component of islet infiltrates in pre-diabetic NOD mice. Eur. J. Immunol. 24:1853-1857.

5.Daniel, D., Gill, R.G., Schloot, N., and Wegmann, D. 1995. Epitope specificity, cytokine production profile and diabetogenic activity of insulin-specific T cell clones isolated from NOD mice. Eur. J. Immunol. 25:1056-1062.

6. Daniel, D., and Wegmann, D.R. 1996. Protection of nonobese diabetic mice from diabetes by intranasal or subcutaneous administration of insulin peptide B-(9-23). Proc. Natl. A cad. Sci. USA. 93:956-960.

7.Wong, F.S., et al. 1999. Identification of an M HC class I-restricted autoantigen in type 1 diabetes by screening an organ-specific CD N A library. Nat. Med. 5:1026-1031.

8. Yoon, J.W., et al. 1999. Control of autoimmune diabetes in NOD mice by GAD expression or suppression in beta cells. Science. 284:1183-1187.

9. Tisch, R., et al. 1993. Immune response to glutamic acid decarboxylase correlates with insulitis in non-obese diabetic mice. N ature. 366:72-75.

10. Bingley, P.J., et al. 1994. Combined analysis of autoantibodies improves prediction of IDDM in islet cell antibody-positive relatives.
Diabetes. 43:1304-1310.

11. al-Attas, O.S. 1995. Correlates of insulin autoantibodies with beta cell function at the time of diagnosis of diabetes mellitus. Am. J. M ed. Sci. 310:138-142.

12. Schloot, N.C., et al. 1997. Altered immuneresponse to insulin in newly diagnosed compared to insulin-treated diabetic patients and healthy control subjects. Diabetologia. 40:564-572.

13. Durinovic-Bello, I., Hummel, M., and Ziegler, A.G. 1996. Cellular immune response to diverse islet cell antigens in IDDM. Diabetes. 45:795-800.

14. Dubois-LaForgue, D., Carel, J.C., Bougneres, P.F., Guillet, J.G., and Boitard, C. 1999. T-cell response to proinsulin and insulin in type 1 and pretype 1 diabetes. J. Clin. Immunol. 19:127-134.

15. Honeyman, M.C., Stone, N., de Aizpurua, H., Rowley, M.J., and Harrison, L.C. 1997. High T cell responses to the glutamic acid decarboxylase (GAD) isoform 67 reflect a hyperimmune state that precedes the onset of insulin-dependent diabetes. J. Autoimmun. 10:165-173.

16. Ellis, T., et al. 1999. Cellular immuneresponses against proinsulin: no evidence for enhanced reactivity in individuals with IDDM . Diabetes. 48:299-303.

17. Sarugeri, E., et al. 1998. Autoimmune responses to the beta cell autoantigen, insulin, and the INS VNTR-IDDM 2 locus. Clin. Exp. Immunol. 114:370-376.

18. Semana, G., Gausling, R., Jackson, R.A., and H afler, D.A. 1999. T cell autoreactivity to proinsulin epitopes in diabetic patients and healthy subjects. J. Autoimmun. 12:259-267.

19. Falorni, A., Ortqvist, E., Persson, B., and Lernmark, A. 1995. Radioimmunoassays for glutamic acid decarboxylase (GAD 65) and GAD 65 autoantibodies using $35 \mathrm{~S}$ or $3 \mathrm{H}$ recombinant human ligands. J. Immunol. M ethods. 186:89-99.

20. Gianani, R., et al. 1995. ICA512 autoantibody radioassay. Diabetes. 44:1340-1344.

21. N aserke, H.E., Dozio, N ., Ziegler, A.G., and Bonifacio, E. 1998. Com parison of a novel micro-assay for insulin autoantibodies with the conventional radiobinding assay. Diabetologia. 41:681-683.

22. Verge, C.F., et al. 1996. Prediction of typel diabetes in first-degree relatives using a combination of insulin, GAD, and ICA512bdc/IA-2 autoantibodies. Diabetes. 45:926-933.

23. Chia, D., Terasaki, P., Chan, H., Tonai, R., and Siauw, P.A. 1993. Direct detection of PCR products for HLA class II typing. Tissue Antigens. 42:146-149.

24. M errifield, R.B. 1963. Solid phase peptide synthesis. I. The synthesis of tetrapeptide. J. Am. Chem. Soc. 85:2149-2154.

25. Tary-Lehmann, M., H ricik, D .E., Justice, A.C., Potter, N.S., and Heeger, P.S. 1998. Enzyme-linked immunosorbent assay spot detection of interferon-gamma and interleukin 5-producing cells as a predictive marker for renal allograft failure. Transplantation. 66:219-224.

26. Kwok, W.W., N epom, G.T., and Raymond, F.C. 1995. H LA-D Q polymorphisms are highly selective for peptide binding interactions. J. Immunol. 155:2468-2476.

27. Ridgway, W.M., Fasso, M., and Fathman, C.G. 1999. A new look at M HC and autoimmune disease. Science. 284:749-751.

28. Reizis, B., Altmann, D.M ., and Cohen, I.R. 1997. Biochemical characterization of the human diabetes-associated HLA-DQ 8 allelic product: similarity to the major histocompatibility complex class II I-A(g)7 protein of non-obese diabetic mice. Eur. J. I mmunol. 27:2478-2483.

29. Rudy, G., et al. 1995. Similar peptides from two beta cell autoantigens, proinsulin and glutamic acid decarboxylase, stimulate T cells of individuals at risk for insulin-dependent diabetes. M ol. M ed. 1:625-633.

30. Roep, B.O., et al. 1996. HLA-associated inverse correlation between T cell and antibody responsiveness to islet autoantigen in recent-onset insulin-dependent diabetes mellitus. Eur. J. Immunol. 26:1285-1289.

31. Swain, S.L. 1995. T-cell subsets. Who does the polarizing? Curr. Biol. 5:849-851.

32. French, M.B., et al. 1997. Transgenic expression of mouse proinsulin II prevents diabetes in nonobese diabetic mice [erratum 1997, 46:924]. Diabetes. 46:34-39.

33. M uir, A., et al. 1995. Insulin immunization of nonobese diabetic mice induces a protective insulitis characterized by diminished intraislet interferon-gamma transcription. J. Clin. Invest. 95:628-634.

34. M aron, R., M elican, N.S., and Weiner, H.L. 1999. Regulatory Th2-type $T$ cell lines against insulin and GAD peptides derived from orally- and nasally-treated NOD mice suppress diabetes. J. Autoimmun. 12:251-258. 